\title{
APARTMENT HOUSE THERMAL REHABILITATION IMPACT ON INDOOR CARBON DIOXIDE RELEASES
}

\author{
P. KAPALO ${ }^{1}$, C. BACOTIU ${ }^{2}$, F. DOMNITA ${ }^{2}$, M. ZELENAKOVA ${ }^{1}$
}

\begin{abstract}
Apartment building thermal rehabilitation impact on indoor carbon dioxide releases. This article continues the research presented at the last year conference by Kapalo et al. (2017) in the article "Renovation of the building and its impact on air pollution". The main purpose of this study is to quantify the amount of carbon dioxide produced inside an apartment building with 90 occupants, before and after the thermal rehabilitation process. As expected, the improving actions on building thermal insulation had a positive effect on energy consumption and, as a consequence, the $\mathrm{CO}_{2}$ footprint of the building decreased significantly. After changing the old wooden windows with new tight ones and after using a heat recovery air handling unit, the values of $\mathrm{CO}_{2}$ production were reduced by $48 \%$, as resulting from the conversion of energy savings due to heating of the building. After applying the thermal insulation on building envelope, the equivalent $\mathrm{CO}_{2}$ releases of the apartment building were reduced to a final value of $40 \%$ compared to the $\mathrm{CO}_{2}$ footprint before the building thermal rehabilitation.
\end{abstract}

Keywords: building thermal rehabilitation, window, indoor air quality, $\mathrm{CO}_{2}$ concentration.

\section{INTRODUCTION}

Carbon dioxide $\left(\mathrm{CO}_{2}\right)$ concentration in the environment increases continuously, mainly in industrial cities. According to last updated data (December 5,2017 ) recorded by Mauna Loa (Hawaii) atmospheric observatory (U.S. National Oceanic and Atmospheric Administration - NOAA), the $\mathrm{CO}_{2}$ concentrations increased during the last year with about $1.61 \mathrm{ppm}$, from $403.53 \mathrm{ppm}$ in November, 2016 to $405.14 \mathrm{ppm}$ in November, 2017 (NOAA, 2017). From the synthesis report "Climate Change 2014" (IPCC, 2014), where the main world environmental changes and their causes are documented, it can be stated that the globally economic growth is one of the most important drivers of increases in $\mathrm{CO}_{2}$ emissions from fossil fuel combustion. From the same study (IPCC, 2014), about $12 \%$ of the world $\mathrm{CO}_{2}$ releases in 2010 are generated, directly or indirectly, by producing the needed energy for buildings in order to ensure their adequate operation. According to MacMath (2000) this fact requires an awareness from the

1 Technical University of Kosice, Faculty of Civil Engineering, 04200 Kosice, Slovakia,

E-mail: peter.kapalo@tuke.sk martina.zelenakova@tuke.sk

2 Technical University of Cluj-Napoca, Building Services Faculty, 400604 Cluj-Napoca, Romania, E-mail: ciprian.bacotiu@insta.utcluj.ro florin.domnita@insta.utcluj.ro 
building industry professionals so they should use in the designing process materials that have a minimal impact on global warming.

This article focuses mainly on the possibility of adjusting the quantity of fresh air needed inside an apartment building with the $\mathrm{CO}_{2}$ releases of the occupants and to theoretical quantification of the energy savings for a standard household from this building.

\section{APARTMENT BUILDING CHARACTERISTICS}

The chosen building for this study is an apartment building with 30 flats. The apartment house is located in a town in the eastern Slovakia with 18 thousand inhabitants. The total built area is $2,390 \mathrm{~m}^{2}$ and the average area of an apartment is about $65 \mathrm{~m}^{2}$. The exposed walls have an area of $877.40 \mathrm{~m}^{2}$, they are made of brick and have two types of thickness: $440 \mathrm{~mm}$, respectively $300 \mathrm{~mm}$. Before rehabilitation, the whole building had old wooden windows with a cumulated area of $242.22 \mathrm{~m}^{2}$. The floor layers were linoleum, concrete, thermal insulation, water insulation, and gravel. The upper floor of the building have attic flats. The total area of sloping roof is $422.06 \mathrm{~m}^{2}$ and it is made of wood with thermal insulation.

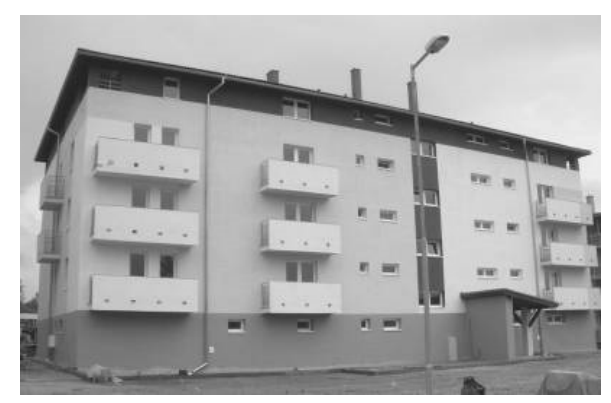

Fig. 1. The apartment building after rehabilitation

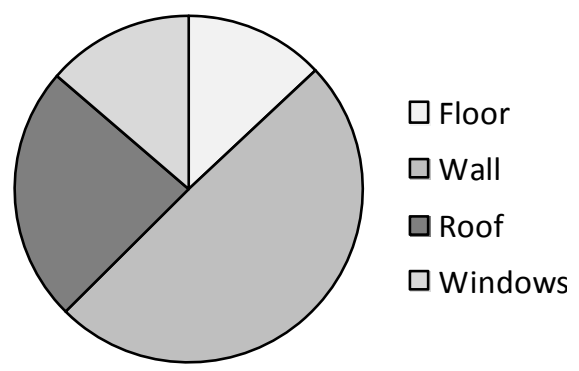

Fig. 2. The partition of building elements in envelope area

In the first phase of the rehabilitation process, the old wooden windows were replaced with new tight, double glazing, plastic windows. A recuperative air handling unit was also installed, in order to provide fresh air inside the building.

In the second phase of rehabilitation, the thermal insulation was added on the exposed exterior walls, roof and floor.

\section{CALCULATION OF $\mathrm{CO}_{2}$ RELEASES}

Before the calculation of $\mathrm{CO}_{2}$ releases, it is needed to determine the energy requirement for heating and for hot water preparation.

The required energy for heating the un-rehabilitated building was calculated according to standard STN 730540 (2016) and the result for the whole 
apartment building was $160,352 \mathrm{kWh} /$ year. In this case, the recuperative air handling unit did not exist and the ventilation was provided naturally, only through infiltration.

After the first phase of rehabilitation, if the fresh air handling unit is used for ventilation at a rate of $n=0.5 h^{-1}$, without heat recovery, the energy needed for heating has a value of $112,147 \mathrm{kWh} /$ year. If the fresh air ventilation rate dropped to $\mathrm{n}=0.15 \mathrm{~h}^{-1}$ and the heat recovery was used, the energy requirement for heating has decreased to $58,776 \mathrm{kWh} /$ year.

In the second phase, beside adding the thermal insulation on the exposed walls consisting of $100 \mathrm{~mm}$ mineral wool, the roof was insulated with $200 \mathrm{~mm}$ XPS hardened polystyrene and the floor with a layer of $80 \mathrm{~mm}$ made of the same material. After adding the thermal insulation, it was calculated the energy requirement for heating of $87,747 \mathrm{kWh} /$ year in the case of a fresh air ventilation rate of $\mathrm{n}=0.5 \mathrm{~h}^{-1}$, without heat recovery. For a fresh air ventilation rate of $\mathrm{n}=0.15$ $\mathrm{h}^{-1}$, with heat recovery, the energy requirement for heating dropped at 34,377 $\mathrm{kWh} /$ year.

After taking into account the energy requirements for heating the building (heating system and hot water preparation system), the $\mathrm{CO}_{2}$ releases were calculated according to STN EN 15316 (2010) and Edict 364 (2012). Both systems were the same for each apartment and consist of an individual gas boiler.

The required energy values, calculated for the apartment building in different scenarios, together with the equivalent $\mathrm{CO}_{2}$ emissions, are documented in Table 1.

Table 1. The required energy values and the equivalent $\mathrm{CO}_{2}$ emissions

\begin{tabular}{|l|c|c|c|}
\hline & $\begin{array}{c}\text { Energy requirement } \\
\text { for heating } \\
\text { (kWh/year) }\end{array}$ & $\begin{array}{c}\text { Equivalent CO } \\
\text { production } \\
\text { (T/year) }\end{array}$ & $\begin{array}{c}\text { Reduction of CO } \\
\text { production } \\
\text { (T/year) }\end{array}$ \\
\hline $\begin{array}{l}\text { Original building state } \\
\text { Ventilation without heat recovery }\end{array}$ & 160,352 & 57.36 & - \\
\hline $\begin{array}{l}\text { Building with new windows, } \\
\text { Intensity of ventilation } \mathrm{n}=0.5 \mathrm{~h}^{-1} \\
\text { Ventilation without heat recovery }\end{array}$ & 112,147 & 44.45 & 12.91 \\
\hline $\begin{array}{l}\text { Building with new windows } \\
\text { Intensity of ventilation } \mathrm{n}=0.15 \mathrm{~h}^{-1} \\
\text { Ventilation with heat recovery }\end{array}$ & 58,776 & 23.29 & 34.07 \\
\hline $\begin{array}{l}\text { Building with thermal insulation } \\
\text { Intensity of ventilation } \mathrm{n}=0.5 \mathrm{~h}^{-1} \\
\text { Ventilation without heat recovery }\end{array}$ & 87,747 & 37.78 & 19.58 \\
\hline $\begin{array}{l}\text { Building with thermal insulation } \\
\text { Intensity of ventilation } \mathrm{n}=0.15 \mathrm{~h}^{-1} \\
\text { Ventilation with heat recovery }\end{array}$ & 34,377 & 13.62 & 43.74 \\
\hline
\end{tabular}

An unavoidable source of indoor $\mathrm{CO}_{2}$ pollution is the human breathing. In order to obtain the $\mathrm{CO}_{2}$ mass flow produced by breathing, experimental measurements were carried out in one of the apartments of the studied building, apartment occupied by a four-member family (Kapalo et al., 2017). There were 
measured the $\mathrm{CO}_{2}$ concentration, the indoor air temperature and relative humidity. Based on the measured values of $\mathrm{CO}_{2}$ concentration, it was calculated the $\mathrm{CO}_{2}$ mass flow rate, produced during several activities: sleeping, sedentary working, nointensive physical working - using the method presented by Kapalo et al. (2014).

The $\mathrm{CO}_{2}$ mass flow rate produced by one person was: $7 \mathrm{mg} / \mathrm{s}$ over sleeping, $11 \mathrm{mg} / \mathrm{s}$ over sedentary activities and $32 \mathrm{mg} / \mathrm{s}$ over no-intensive physical work. Based on these values, the total production of $\mathrm{CO}_{2}$, released during breathing for the all 90 occupants of the apartment building was estimated at $40.05 \mathrm{t} /$ year.

The replacement of the electrical equipment in the studied household with a new, energy-efficient equipment generated an important decrease of energy consumption, from $102,000 \mathrm{kWh} /$ year to $51,930 \mathrm{kWh} /$ year. For a better comparison between the five different situations studied in this research, the carbon footprint is presented in Table 2 .

\section{RESULTS}

One of the goals of this research was to evaluate how much $\mathrm{CO}_{2}$ is released into atmosphere from the studied apartment building with 90 residents. In Table 2 we presented the overall results, from which come into view the different $\mathrm{CO}_{2}$ production ratios, before and after the actions taken in order to reduce the $\mathrm{CO}_{2}$ production of the whole building.

Table 2. The $\mathrm{CO}_{2}$ production before and after the building rehabilitation

\begin{tabular}{|c|c|c|c|c|}
\hline & $\begin{array}{c}\text { Equivalent } \mathrm{CO}_{2} \\
\text { production for } \\
\text { heating the } \\
\text { building } \\
\text { (T/year) } \\
\end{array}$ & $\begin{array}{c}\mathrm{CO}_{2} \\
\text { production } \\
\text { from electrical } \\
\text { equipment } \\
\text { (T/year) } \\
\end{array}$ & $\begin{array}{c}\mathrm{CO}_{2} \\
\text { production } \\
\text { from } \\
\text { breathing } \\
\text { (T/year) } \\
\end{array}$ & $\begin{array}{c}\text { Total } \\
\text { production } \\
\text { of } \mathrm{CO}_{2} \\
\text { (T/year) }\end{array}$ \\
\hline $\begin{array}{l}\text { Original building state } \\
\text { Ventilation without heat recovery }\end{array}$ & 57.36 & 51.00 & \multirow{5}{*}{40.05} & 148.41 \\
\hline $\begin{array}{l}\text { Building with new windows, } \\
\text { Intensity of ventilation } n=0.5 \mathrm{~h}^{-1} \\
\text { Ventilation without heat recovery }\end{array}$ & 44.45 & \multirow{4}{*}{24.00} & & 108.50 \\
\hline $\begin{array}{l}\text { Building with new windows } \\
\text { Intensity of ventilation } n=0.15 \mathrm{~h}^{-1} \\
\text { Ventilation with heat recovery }\end{array}$ & 23.29 & & & 87.34 \\
\hline $\begin{array}{l}\text { Building with thermal insulation } \\
\text { Intensity of ventilation } n=0.5 \mathrm{~h}^{-1} \\
\text { Ventilation without heat recovery }\end{array}$ & 37.78 & & & 101.83 \\
\hline $\begin{array}{l}\text { Building with thermal insulation } \\
\text { Intensity of ventilation } n=0.15 \mathrm{~h}^{-1} \\
\text { Ventilation with heat recovery }\end{array}$ & 13.62 & & & 77.67 \\
\hline
\end{tabular}

From the results presented in Table 2, it can be seen that the most important contribution to $\mathrm{CO}_{2}$ production (ninety persons living in the apartment building) was generated by heating the original building or by heating the building with new windows without heat recovery ventilation. After applying the thermal insulation and the heat recovery ventilation, the energy consumption for heating the 
building has decreased and, as a consequence, the equivalent $\mathrm{CO}_{2}$ production values dropped significantly. In this case, the largest amount of $\mathrm{CO}_{2}$ production was released through the occupants' breathing process. Sealing the building (new thermal insulation and windows replacement) significantly reduces outdoor air infiltration rate and therefore generates a decreasing of $\mathrm{CO}_{2}$ production corresponding to fresh air heating for ventilation. The replacement of electrical household appliances reduces the $\mathrm{CO}_{2}$ emissions by $53 \%$. The $\mathrm{CO}_{2}$ production from apartment building occupants remains unchanged in all situations. Overall, taking into account all the five studied scenarios, after rehabilitation measures the $\mathrm{CO}_{2}$ production rate decreases significantly.

One of the easy and effective ways to conserve the energy is through building insulation (Paraschiv, 2017). An equivalent of $1,5 \mathrm{~kg}$ of $\mathrm{CO}_{2}$ is released during the fabrication process of $1 \mathrm{~kg}$ of mineral wool and $3 \mathrm{~kg}_{\text {of }} \mathrm{CO}_{2}$ is generated from the polystyrene manufacturing process (MacMath, 2000). In the case of our studied apartment building, a total of $203.57 \mathrm{~m}^{3}$ of thermal insulation (mineral wool and polystyrene) is needed. Therefore, during its fabrication processes, an equivalent of approximately $8.55 \mathrm{t}$ of $\mathrm{CO}_{2}$ were produced, much less than the saved quantity of $\mathrm{CO}_{2}$ due to reduced energy requirements for heating the building.

According to Meggers (2012) material usage in buildings must include consideration for the emissions of the material. The $\mathrm{CO}_{2}$ emissions from buildings must also be evaluated as a standard part of the design process.

\section{CONCLUSIONS}

This paper studies the effect of thermal rehabilitation actions carried out to an apartment house in order to reduce the energy consumption and subsequently, to decrease the building $\mathrm{CO}_{2}$ footprint. Also, based on the experimental measurements performed in a four-member apartment, it was calculated the $\mathrm{CO}_{2}$ production in the case of several domestic activities performed by one person. Next step was to calculate the total quantity of $\mathrm{CO}_{2}$ produced by the whole four-member family (around $40.05 \mathrm{t} / \mathrm{year}$ ). Out of the equivalent total of $148.41 \mathrm{t} / \mathrm{year}$ of $\mathrm{CO}_{2}$ generated by a non-insulated building with older electrical appliances, the occupants contribution is $27 \%$. After the apartment building rehabilitation (thermal insulation was added, windows and doors were replaced, new energy-efficient electrical appliances were adopted and ventilation with heat recovery was in service), the total output of $\mathrm{CO}_{2}$ decreased by approximately $50 \%$.

\section{Acknowledgments.}

This article was elaborated within the framework of the project VEGA 1/0697/17 and VEGA 1/0307/16. 


\section{REFERENCES}

1. Kapalo, P., Bacotiu, C., Domnita, F., Zelenakova, M. (2017), Renovation of a building and its impact on air pollution, Proceedings of the Conference "Air and water components of the environment”, Cluj-Napoca, Casa Cărţii de Ştiinţă, 2017 pp. 311-316, ISSN 2067-743X;

2. Kapalo, P., Domnita, F., Lojkovics, J. (2014), Methodology for calculating the fresh air ventilation airflow rate based on $\mathrm{CO}_{2}$ concentration, Pollack Periodica, vol. 9 (2), pp. 89-97;

3. Kapalo, P., Vilcekova, S., Domnita, F., Bacotiu, C., Voznyak, O. (2017), Determining the ventilation rate inside an apartment house on the basis of measured carbon dioxide concentrations - case study, ICEE 2017, Technical University of Vilnius, pp. 1-6, ISBN 978-609-476-044-0;

4. MacMath, R. (2000), Carbon dioxide intensity ratios: A Method of Evaluating the Upstream Global Warming Impact of Long-Life Building Materials, http://www.cmpbs.org/publications/T1.2-AD4.5-UpGblwrm.pdf, accessed on December, 6, 2017;

5. Meggers F., Leibundgut H., Kennedy S., Qind M., Schlaich M., Sobek W., Shukuya M. (2012), Reduce CO2 from buildings with technology to zero emissions. Sustainable Cities and Society. Vol. 2, Issue 1, February 2012, Pages 29-36

6. Paraschiv L. S., Paraschiv S., Ion V. I. (2017), Increasing the energy efficiency of buildings by thermal insulation, Energy Procedia, Volume 128, September 2017, Pages 393-399

7. *** (2004), Carbon Footprint Ltd (2016), carbon footprint calculator for individuals and households, Worting House, Church Lane, Basingstoke, Hampshire, RG23 8PX, http://www.carbonfootprint.com/calculator.aspx, accessed on November, 21, 2017;

8. *** (2010), STN EN 15316 - Energy performance of buildings. Method for calculation of system energy requirements and system efficiencies - Part 1: General and Energy performance expression, European Standard STN EN 15316;

9. *** (2012), Edict 364, Ministry of Transport, Construction and Regional Development of the Slovak Republic, November, 12, 2012, law No 555/2005, collection of laws on the energy efficiency of buildings;

10. *** (2014), IPCC Climate Change: Synthesis Report. Contribution of Working Groups I, II and III to the Fifth Assessment Report of the Intergovernmental Panel on Climate Change, Geneva, Switzerland,

http://ar5-syr.ipcc.ch/ipcc/ipcc/resources/pdf/IPCC_SynthesisReport.pdf, accessed on December, 5, 2017;

11. *** (2016), STN EN 730540 - Thermal protection of buildings. Thermal performance of buildings and components, European Standard STN EN 730540.

12. *** (2017), NOAA - National Oceanic and Atmospheric Administration at Mauna Loa in Hawaii. Earth System Research Laboratory. Global Monitoring Division. Trends in Atmospheric Carbon Dioxide, , Data provided by Carbon Cycle and Greenhouse Gases group, 325 Broadway R/CSD, Boulder, CO 80305, https://www.esrl.noaa.gov/gmd/ccgg/trends/index.html, accessed on December, 6, 2017 ; 